\begin{tabular}{|l|c|c|}
\hline $\begin{array}{l}\text { Word and Text } \\
\text { A Journal of Literary Studies and Linguistics }\end{array}$ & Vol. XI & $135-146$ \\
\hline
\end{tabular}

\title{
An Animal Counter-Textuality? Sounding the Dog in the Global South
}

\author{
Anna Frieda Kuhn \\ University of Würzburg \\ E-mail: anna_frieda.kuhn@uni-wuerzburg.de
}

\begin{abstract}
The visual bias in the West has decisively shaped literary and cultural criticism in the past decades. Perpetuated by the linguistic turn, this bias has seen the written word placed firmly at the heart of (post-)humanist critique. Surveying current trends in contemporary theory, it soon becomes evident that, coinciding with the decline of the linguistic turn, Animal and Sound Studies have been on a steady rise. Increasingly shaping the global literary imagination, canine poetics, in particular, are enmeshed in a complex ideological web. Basing my investigation on literary and dramatic works from the Global South, such as Mark Fleishman et al.'s Antigone (Not Quite/Quiet) (2019), Craig Higginson's Dream of the Dog (2007), and Ari Gauthier's Carnet secret de Lakshmi (2015), I argue that, analogous to the way sound has gained increased agency in the Global South, so too canine figurations point to the way acoustic symbols can be rearticulated.
\end{abstract}

Keywords: Global South, canine imaginaries, sound studies, sonic resistance, the Symbolic

With the development of sound technologies in the late $19^{\text {th }}$ century, modernity's audible landscape changed drastically. ${ }^{1}$ These altered acoustic environments are the impetus behind the emergence of 'Sound Studies' in the 1990s: 'By analysing both sonic practices and the discourses and institutions that describe them, it re-describes what sound does in the human world, and what humans do in the sonic world', ${ }^{2}$ says the prominent sound theorist Jonathan Sterne in describing this now well-established field. ${ }^{3}$ Although, since Plato, ${ }^{4}$ considerations on the changing nature of the sonic have been more or less prominent, the way sound has historically and ideologically been framed as

\footnotetext{
${ }^{1}$ Martin Heidegger pointed to the way new sound media acted upon its environment in his Being and Time (Sein und Zeit), arguing that radio (Rundfunk) acts as an extension of the everyday world. Placing sound on par with other senses, Heidegger is an early example of a theorist that questioned the popular hierarchization of sight over hearing in philosophy. Martin Heidegger, Sein und Zeit (Tübingen: Max Niemeyer, 1967), 105.

${ }^{2}$ The Sound Studies Reader, ed. and intr. Jonathan Sterne (Abingdon: Routledge, 2012), 2.

${ }^{3}$ Although Sterne offers a comprehensive delimitation of Sound Studies, the field is somewhat elusive, as it includes phenomena as varied as speech, music, nationalism, the philosophy of history and power. And, as this article will show, although the field is academic in nature, it can move beyond the confines of the university space. It should also be pointed out that, although the dominance of the visual archive is partly rooted in the fact that technology for sound recording did not exist until the late $19^{\text {th }}$ century, the exact reasons why Sound Studies have gained such momentum during this period in literary and cultural history remain unclear.

${ }^{4}$ Plato, Plato in Twelve Volumes, vol. 9, trans. Harold N. Fowler (Cambridge, MA: Harvard University Press, 1925).
} 
the Other of vision has largely gone under-theorised. ${ }^{5}$ In their Remapping Sound Studies (2019), ${ }^{6}$ the ethnomusicologists Gavin Steingo and Jim Sykes confront this lack, arguing that sound and South can easily be substituted for several essentialist and injurious terms, such as 'nature', 'native', 'Africa', 'black', and 'woman'. This, they contend, has strong implications for the way the Global South as a geopolitical space is construed. $^{7}$ The field of Sound Studies is, in other words, subject to a bias, with theorists positioned in the Global North largely having consolidated the notion that sound has historically been associated with 'the South' and the written word with 'the North'. ${ }^{8}$ And although Steingo and Sykes argue that the association of sound with the Global South can be traced back to Jean-Jacques Rousseau (since Rousseau, they argue, the South has corresponded to the Other of sound, music and nature, whereas the North has been associated with vision and writing), this linkage can already be traced to the Early Modern Period. ${ }^{9}$ As a result, sound phenomena have remained at the epistemological margins, with the hegemony of the Global North placing sound and the South at the peripheries of a globalized world.

Although correlation does not necessarily equal causality, a brief survey of current trends in contemporary theory shows that, coinciding with the decline of the linguistic turn, Animal and Sound Studies have been on a steady rise. ${ }^{10}$ Partly basing my investigation on scholars associated with the posthuman turn, such as Donna Haraway, I then argue that canines and their relationship to sound become placeholders for acts of Othering in the $21^{\text {st }}$ century. The focus on sonic agency within the non-human Other, this paper suggests, however, also becomes a mode of critique and resistance. ${ }^{11}$ The

\footnotetext{
${ }^{5}$ Most sound theorists, as Steingo and Sykes have pointed out, start their analyses by surveying Jacques Derrida's deconstruction of voice/writing, sound/vision, and presence/distance. Remapping Sound Studies, ed. and intr. Gavin Steingo and Jim Sykes (Durham, NC: Duke University Press, 2019), 3. Notwithstanding Derrida's invaluable work on phonocentrism and logocentrism, his deconstructive efforts have been overshadowed by theorists such as Walter Ong and Marshall McLuhan, who clearly posit sound and voice as Other.

${ }^{6}$ Steingo and Sykes, 2.

${ }^{7}$ Whether in public discourse or in academic settings, the former designation 'Third World' has, postCold War, been replaced with the discursive entity called the 'Global South'. Aware of the fraught nature of the term, this article is in keeping with the employment of the concept as proposed by Russell WestPavlov, who defines the Global South as both 'a geopolitical area' and a 'body of theories'. For more on West-Pavlov's conception of the term, see The Global South and Literature, ed. and intr. Russell WestPavlov (Cambridge: Cambridge University Press, 2018), 2.

${ }^{8}$ Steingo and Sykes, 3.

9 This was discussed by the scholar Emilie Murphy in a recent paper presentation at the University of Oxford. Her presentation pointed out that such Othering was already present in the works of Francis Drake, Fynes Moryson, and William Lithgow, among others. Emilie Murphy, 'The Racialisation of Sound and Listening in Anglophone Travel Narratives, c. 1550-1650', in Travel, Transculturality, and Identity in England, c. 1550-1700; available at http://www.tideproject.uk/wpcontent/uploads/2021/07/TIDE_On-Belonging-2_Conference-Pack.pdf [accessed 6 September 2021]. See also Jennifer Lynn Stoever's compelling Sonic Color Line (2016) for the racialization of voice in America.

${ }^{9}$ Steingo and Sykes, 3 .

10 See, for example, Sarah Kay, 'The Soundscape of Troubadour Poetry, or, How Human is Song' Speculum 91.4 (2016): 1002-15 and Sarah Kay and Nicolette Zeeman, 'Versions of the Natural', Journal of Medieval and Early Modern Studies 49.3 (2019): 445-56 for the relationship between sound and animal studies. The latter highlights the fraught relationship between nature and culture and, in consequence, the human and the non-human.

${ }^{11}$ Steingo and Sykes also point out that ' $[\mathrm{t}]$ he North is often presumed to be the home of rationality and science; the South, of irrationality and magic. Precisely because they seem to evade the epistemic grip of
} 
idea of 'sonic agency', as proposed by Brandon LaBelle, is of particular interest here. 'Sonic Agency', he contends, 'places particular emphasis on the social experiences and productions of sound and audition, and how a sonic sensibility may inform emancipatory practices. From the continuous flow and punctuations of the audible a range of capacities and potentialities may be found.' 12 Jeremy Bentham's panopticon, well-known in theory circles by way of Foucault, also points to this much-neglected fact about sonic agency. The scholars James A. Steintrager and Rey Chow highlight this in their discussion of Bentham's panopticon:

\begin{abstract}
Interestingly, Bentham considered a prisoner's ability to make 'noise' as the sole weakness of his system: resistance as sonic externalization rather than visual internalization [...]. These questions and comparisons seem to demand for sound an order of conceptualization that is distinct from the visually oriented, an order that, to be specific, runs counter to the concreteness and the alluring - indeed, blinding - obviousness of the visual. ${ }^{13}$
\end{abstract}

If we substitute 'prisoner' with the Other, we arrive at a productive mode of enquiry that allows us to highlight the articulations of the relationship between sound/nature and the Global South. In such a reading, sound's agency is derived from that which has been the cause of its Othering: its opposite being in the visual. The negative act of Othering can therefore become a positive, creative source of agential power.

In order to see how this functions in literatures from the Global South, I locate my analysis at the nexus of South African and Indian acoustic/canine encounters. I chose these spaces because of the commonalities in the way both 'dogs' and 'sound' figure here. This does not mean glossing over the diverse articulations of sound and animality in these areas, but rather finding points of overlap so as to use strategically the concept of the Global South. Starting out with Mark Fleishman et al.'s workshopped play, Antigone (Not Quite/Quiet) (2019), I will then discuss the figurations of canine/acoustic presences in the literary imagination of Craig Higginson's acclaimed drama, Dream of the Dog (2007) and Ari Gauthier's novelized rewriting of Pondicherrian history in Carnet secret de Lakshmi (2015). ${ }^{14}$ In the Global South, as this paper seeks to demonstrate, non-human Others are not just passive objects of investigation, but active agents in their own right (whose agency, however, should not be equated with anthropocentric agency). In the same way, as the function of sound (specifically in the form of orality and music) has gained increased agency in the Global South, so too the figure of the dog points to the way these symbols can liberate themselves through resistance.

\footnotetext{
Western reason, sound and the South are frequently offered as radical alternatives to the dilemmas of modernity. The problem here, as many have noted, is that celebrating "sound and the South" against "vision and the North" reaffirms the binary opposition on which all of the terms depend'. Steingo and Sykes, 2.

12 Brandon LaBelle, Sonic Agency: Sound and Emergent Forms of Resistance (London: Goldsmiths Press, 2018), 2.

${ }^{13}$ Sound Objects, ed. and intr. James A. Steintrager and Rey Chow (Durham, NC: Duke University Press, 2019), 6.

14 As Jonathan Sterne contends in his Sound Studies Reader, the challenge of sound studies 'is to think across sounds, to consider sonic phenomena in relationship to one another - as types of sonic phenomena rather than as things-in-themselves - whether they be music, voices, listening, media, buildings, performances, or another path into sonic life' (3). The latter also highlights the importance of moving beyond a mere neo-Heideggerian quest for the essence of 'sound' to understanding the relationship these sonic phenomena have with one another.
} 
The German media theorist Friedrich Kittler who, much in the tradition of $18^{\text {th }}$ and $19^{\text {th }}$-century German Hellenophile scholarship, turns to Greece to construct a media theory ranging from the ancients to the moderns, is helpful in understanding the function of sound today. Kittler, arguing for the necessity of moving beyond a 'contentbased' literary analysis to one focused on the material conditions forming a literary work, radicalizes McLuhan's most infamous axiom that the 'medium is the message'. In what seems to be a polemic against a peculiarly Foucauldian discourse analysis, he elaborates his media theory:

Texts and scores - Europe had no other means of storing time. Both are based on a writing system whose time is (in Lacan's term) symbolic. Using projections and retrievals, this time memorizes itself - like a chain of chains. Nevertheless, whatever ran as time on a physical or (again in Lacan's terms) real level, blindly and unpredictably, could by no means be encoded. Therefore, all data flows, provided they really were streams of data, had to pass through the bottleneck of the signifier. Alphabetic monopoly, grammatology. ${ }^{15}$

Kittler further explicates how, with the absence of conceptualizations of media in general, sound archives, in particular, have largely been ignored within discourse analysis. He points to the hegemony of the written archive, highlighting how the archival processes of sound have historically been dominated by the visual. In the Global North, ideograms, texts and scores evolved as the medium of choice for the storage of time. Subsequently, both have been fixed firmly in the (Lacanian) Symbolic. ${ }^{16}$ Sound, on the other hand, could not be encoded and is, therefore, located on the Real: blind and unpredictable, able to elude the Symbolic. As Kittler contends: 'Discourse analysis cannot be applied to sound archives [...]. More simply, but no less technically than tomorrow's fiber optic cables, writing functioned as a universal medium in times when there was no concept of medium. Whatever else was going on dropped through the filter of letters or ideograms.' ${ }^{17}$ The neglect of sound archives within discourse analysis has had a lasting effect on both Global South Studies and Sound Studies. Here, as will be discussed in more detail in the following, sound through its association with the physical and the Real, has been relegated to the Other of sound and the South.

The modern sound/animal fusion is exemplified in Mark Fleishman et al.'s recent South African Antigone adaptation, Antigone (Not Quite/Quiet) (2019), subtitled Ninganiki Okungcwele Ezinjeni (isiXhosa for 'Give not unto dogs sacred things'). ${ }^{18}$ The subtitle of the play figures as a New Testament reference that constructs the Other of

\footnotetext{
${ }^{15}$ Friedrich Kittler, Gramophone, Film, Typewriter (Stanford, CA: Stanford University Press, 1999), 4.

16 'The psychoanalytic experience has rediscovered in man the imperative of the Word as the law that has formed him in its image', says Jacques Lacan. 'It manipulates the poetic function of language to give to his desire its symbolic mediation. May that experience enable you to understand at last that it is in the gift of speech that all the reality of its effects resides; for it is by way of this gift that all reality has come to man and it is by his continued act that he maintains it.' Jacques Lacan, Ecrits: A Selection, trans. Alan Sheridan (London: Routledge, 2001), 106. In this sense, literature has a peculiar weight in the formation of the Symbolic, which includes not only language as such but the whole domain of culture.

17 Kittler, 5.

18 The recording referenced here was filmed by Dex Goodman in 2019 at the Golden Arrow Studio, Baxter Theatre Centre, Cape Town. I offer my profound gratitude to Jayne Batzofin and Mark Fleishman, who shared full video footage of Antigone (Not Quite/Quiet) with me. Thank you also to Carlo Daniels, who gave me valuable insight into the creative process of Antigone (Not Quite/Quiet).
} 
dogs as an act of injurious speech in the South African context. ${ }^{19}$ Likewise, in India, large swathes of the middle and upper classes have historically employed this injurious speech act, ${ }^{20}$ thereby setting themselves apart from the lower castes and classes. Although the racial and caste implications of dogs are made explicit in both South African and Indian literature, as the increased interest in Animal and Sound Studies in recent years attests, we see how once injurious speech acts are gaining subversive agency to counter negative interpellations. ${ }^{21}$ In the texts discussed below, I, therefore, hope to show the way sound and animality act as malleable concepts no longer solely fettered to a Symbolic monopoly. ${ }^{22}$

Fleishman et al.'s Antigone (Not Quite/Quiet) is a loose adaptation of Sophocles' Antigone, that traces the concerns of decolonial, post-apartheid South Africa through the ancient characters of Ismene, Antigone, and Tiresias. ${ }^{23}$ The production makes use of these distinctive parts to highlight the relevance of the Antigone figure for contemporary South Africa. The play's director, Mark Fleishman, explicitly draws on sonic, oral forms, as they cannot, as Plato suggests, "be written down to be "looked up" at a later date'. ${ }^{24}$ Building on semantic and non-semantic dialogue and song, the play becomes a means of dealing with a nation split along legal, economic, gender, ${ }^{25}$ and generational lines. Calcified within the literary imagination of South Africa, we especially see how the varied articulations of canines - reflective of the country's disunity - are stuck in a complex double bind. This falls in line with what South African scholar and poet Gabeba Baderoon illustrates in her 'Animal Likenesses: Dogs and the Boundary of the Human in South Africa', the figure of the dog has an intricate relationship with South African subjectivity that traces back to precolonial spaces. These canine imaginaries are interwoven with ideas about race and speciesism. Baderoon succinctly summarizes this in the following terms: 'Racialized canine invective played a formative role in colonial efforts to dispossess Africans of land.

\footnotetext{
${ }^{19}$ Injurious speech is used in the sense put forth by Judith Butler in her Excitable Speech: A Politics of the Performative (2019). Judith Butler does more than simply employ the Althusserian notion of interpellation; she expands it, arguing that language itself interpellates and acts as injurious speech, even if not directly called or hailed. The fact that we understand the codes and signals presented to us within a piece of literature or any piece of art that uses language as a medium for that matter, Butler argues, means that we become interpellated. Text and language can, however, be rearticulated: '[I]f the text acts once', Butler contends, 'it can act again, and possibly against its prior act. This raises the possibility of resignification as an alternative reading [...].' Judith Butler, Excitable Speech: A Politics of the Performative (New York: Routledge, 1997), 69.

${ }^{20} \mathrm{~S}$. Theodore Baskaran argues that historically in India 'the dog was despised, and the word "dog" was used as a derogatory term in daily usage and in literature'. S. Theodore Baskaran, The Book of Indian Dogs (New Delhi: Aleph, 2017), 10.

${ }^{21}$ Notably, how nature has historically been understood as independent from culture meant a foreclosure of considerations of literature as a mechanism that shapes and produces understandings of nature. The literature/science and nature/culture dichotomies have thus had major implications for how species concepts and animality have historically been perceived.

${ }^{22}$ Kittler, 12.

${ }^{23}$ For more on the importance of Greek tragedy as a means of resistance, see Emily Katz Anhalt, Embattled: How Ancient Myths Empower Us to Resist Tyranny (Stanford, CA: Redwood Press, 2021).

${ }^{24}$ Mark Fleishman, 'Workshop Theatre in South Africa in the 1980s: A Critical Examination with Specific Reference to Power, Orality and the Carnivalesque' (MA Thesis University of Cape Town, 1991): 31-2.

${ }^{25}$ For more on sound studies and a feminist black intellectual tradition, see Daphne A. Brooks, Linear Notes for the Revolution: The Intellectual Life of Black Feminist Sound (Cambridge, MA: Harvard University Press, 2021).
} 
However, the symbolic meanings of dogs in South African culture range far beyond insult. Recent portrayals of canines have turned suggestively, if equivocally, from denigration toward signalling post-apartheid racial authenticity. ${ }^{26}$

The relationship between human and animal subjectivity is perhaps most prominently considered by the posthumanist scholar Donna Haraway, who aims at countering the dominant discourse, particularly in the life sciences, associated with hierarchization and competition amongst species and entities. ${ }^{27}$ Haraway argues that "through our ideologically loaded narratives of their lives, animals "hail" us to account for the regimes in which they and we must live. We "hail" them into our constructs of nature and culture, with major consequences of life and death, health and illness, longevity and extinction'. ${ }^{28}$

Particularly in Antigone (Not Quite/Quiet), we see how such forms of racialization and speciesism have become infinitely more complex in recent years, as the third act of the play, entitled 'Tiresias', shows. This final act, an audio-visual adaptation of the late South African poet S.E.K. Mqhayi's 'Mbambushe - Lwaganda's Favourite Dog', is suggestive of some of the metamorphoses canine conceptions have undergone. Mqhayi's poem, now integrated into the play, reads as follows:

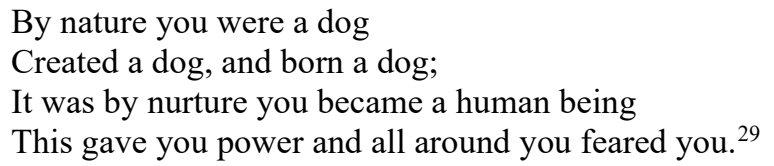

As a South African poet and person of colour, S.E.K. Mqhayi uses the figure of the dog to describe power abuses, labelling (fascistoid) political figures as dogs, rather than rearticulating the canine metaphor in purely racial terms. The Fleishman production, which critically engages with the legacy of dogs in South Africa, is nevertheless bound by metaphorical and injurious implications, where the dog is treated as a figure that must become 'more than animal', if it wants to act agentially. In other words, Lwaganda's favourite dog gains agential power only by 'vertically' flattening the nature/nurture and nature/culture divides by becoming 'a human being'. In this, the play highlights how agency is not only distributed among different species and entities, but how this agency is only acquired through anthropomorphization. ${ }^{30}$ This also holds true for Higginson's play, which illustrates how white South Africa has historically

26 Gabeba Baderoon, 'Animal Likenesses: Dogs and the Boundary of the Human in South Africa', Journal of African Cultural Studies 29.3 (2017): 345.

27 Especially the way this relates to the canine Other is explicated in her The Companion Species Manifesto: Dogs, People, and Significant Otherness (2003).

${ }^{28}$ Donna Haraway, When Species Meet (Minneapolis: University of Minnesota Press, 2008), 278.

29 Mandisa Vundla, 'Texts: Antigone Responses'; available at https://retags 100.wixsite.com/retagsproductions/antigone-not-quite-quiet-1 [accessed 26 February 2021].

30 In her 'Posthumanist Performativity' (2003), Karen Barad overtly critiques semio-linguistic-centred understandings of agency as spearheaded by Judith Butler. In contrast, Barad proposes 'a specifically posthumanist notion of performativity'. Conjuring Donna Haraway's views on posthumanism, she argues for a consideration of the materialization of both human and non-human bodies, ably navigating an account of materiality that neither over- nor under-emphasizes the discursive. Rather, it calls for a consideration of both the discursive and the material when looking at the construction of reality. The reality of the world, in Baradian parlance, is continual and open - a process of mattering. Discourse, then, so Barad, is not primarily linguistic, with words and things having agency only within 'intra-activity'. Karen Barad, 'Posthumanist Performativity: Toward an Understanding of How Matter Comes to Matter', Signs Journal of Women in Culture and Society 28.3 (2003): 820. 
employed the term 'dog' as a derogatory demarcation to describe non-white South African subjectivity.

Dream of the Dog is a play that revisits the presumed rape of a woman of colour, Grace, by a white farmer. The play pivots on a former employee, Look Smart, describing how the incident was covered up as a dog attack:

Suddenly, Grace is a double creature. Half woman, half dog. She utters a sound so terrible I don't even recognize it as her, as coming from her. But it brings a dozen farmworkers into the garden within seconds. We gather around, worshippers around some - ancient sacrifice. Silent with terror. Whenever I try to approach, the dog swivels around so that Grace stands between us. [...] And Grace, she is wailing in a strange, song-like way. She utters the same few notes repeatedly, obsessively, as if her voice has found the right level, the right pitch, the right song for the pain.

Entering the realm of the fully acoustic and non-linguistic, Grace is moved to the domain of the non-human. In this, the passage above foregrounds the impossibility of fully delivering through the written word that which necessitates bodily representation. In other words, Grace's cry points not only to the fetters of racial invective, but also generally to the grammatological/ideogrammatical chains of the Symbolic. The latter thus moves the play beyond Symbolic representation and, rather than promoting order, fosters a sonic resistance through the body - the cry. ${ }^{31}$ This figures as a means of 'resistance as sonic externalization', in the sense proposed by Jeremy Bentham. In their foregrounding of animality and sound, the plays discussed here thus contribute to the formation of identity beyond the socio-caste/racial and animal divide - a world of new symbols, as Nietzsche puts it elsewhere. ${ }^{32}$ Arguably, Look Smart's description of Grace as being 'half woman, half dog' when she is attacked, also conjures the sonic/animal imaginary of J. M. Coetzee's award-winning South African farm novel Disgrace (1999). The latter novel centres on the rape of two women: one 'white' and one 'black'. In a reversal of the canine-racial metaphoric, the white protagonist, David Lurie, is described in similar terms; he too has undergone a literary transfiguration into a 'dogman, a dog undertaker, a dog psychopomp, a harijan'. ${ }^{33}$

While sound is able to circumvent the Symbolic in the employment of nonhuman, animal sound elements in Dream of the Dog, in Antigone (Not Quite/Quiet) subjectivity moves beyond the logos of the scripted text. After performing a barking duet in the second 'act' of the play, two non-white Antigone figures emerge from the commonality of the chorus. The non-linguistic barking act then creates a moment where voice manages to escape the fetters of the Symbolic, thus eluding semantic readability. This aggressive dog barking, which sporadically takes hold of the play's dialogue, is perhaps the most frequently used non-human sound in the play. Corresponding to the

\footnotetext{
${ }^{31}$ Arguably the markers 'ancient' and 'song-like' also bring to mind Nietzsche, who starkly separates the Apollonian from the Dionysian. He argues that the peculiarly non-Apollonian element is that which is carefully kept away from 'high culture'. This defines the character of the Dionysian in music and, with it, music in general. To express music, then, means creating a new world of symbols (eine neue Welt der Symbole). Friedrich Nietzsche, Die Geburt der Tragödie: oder Griechentum und Pessimismus (Berlin: Hofenberg, 2016), 22. Nietzsche, as the American critic Fredric Jameson reads him, therefore sees in the Apollonian a world dominated by the visual sense, whereas the Dionysian is a world ruled by the sonic. It is, in keeping with Jameson's reading, a non-Symbolic form that reaches its zenith in music. See Fredric Jameson, The Ancients and the Postmoderns: On the Historicity of Forms (London: Verso, 2015), 7.

${ }^{32}$ Nietzsche, 22.

${ }^{33}$ J. M. Coetzee, Disgrace (New York: Viking Adult, 1999), 146.
} 
way the function of orality and sound has gained increased agency in the Global South, the metaphor of the dog, represented here by cacophonous barking, points to the way these symbols can liberate and rearticulate themselves. Just as dogs are part of complex figurations for South Africa's so-called born-free generation, the figure of the dog, as conceptualized here, acts both as metaphor and metonymy, standing in for the varied articulations of sound. In Dream of the Dog, however, the inexpressibility of what, through the lens of Look Smart, is a brutal rape, positions Grace on the level of the Real, the sonic, and the non-human. Here sound, South, and animality are equally treated as Other. It is a realm that eludes comprehension; exemplified in the sound Grace made after being attacked by the farm dog not being 'recognized as her'. The use of the descriptors 'ancient', 'song-like' and 'silent with terror', in the description of the attack, add to her alienation and Othering. Such binaries are strongly reminiscent of evolutionist views of $19^{\text {th }}$-century music based on the fundamental binary self/Other. And although there is much awareness around such ideologies of old/modern and savage/civilized implied in such thinking, the dichotomy between tradition/modernity and the African/Western continues in present-day thinking about sound (in its manifestation as music). This holds true especially for South Africa and the Global South, where other frequently used couples, such as individual/communal and urban/rural figure prominently. ${ }^{34}$ In Dream of the Dog, we thus see the explicit racialization of non-white, subaltern bodies in their equation with 'dogs'. Notably, the canine metaphoric peaks when Look Smart points out that the domestic worker, Grace, only responds to her boss, or 'madam' if she does so as she would one of her dogs; in a somewhat crude likening to 'H[er] Master's Voice'. ${ }^{35}$ Likewise, the voice of the now half-animal Grace is related as a sonic encounter that cannot be en- and decoded through linguistic means, thereby escaping what Kittler would term the Symbolic.

Ari Gauthier's novel functions both in similar and markedly different ways to the two dramatic texts discussed above. In a deconstructive manner, ${ }^{36}$ Gauthier imagines an alternative history of French-ruled Pondicherry and figures a speaking dog to do so. When the narrating dog is first introduced, we clearly see these acoustic/animal imaginaries foregrounded:

\footnotetext{
That's why they call him Tripod: because he has only three legs; well, three and a half legs. And Tripod became Tripod Dog Baba after his stay in Rameswaram. When the cleaning is over, he stands on his hind legs.

'First of all, you better call me by my real name: Tripod Dog Baba! Not Tripod, not Dog Baba, and not Tripod Baba either. All my life I've suffered from not having a name; now that I have one, I don't want to have it spelt out. Do you understand?'37
}

\footnotetext{
${ }^{34}$ The World of South African Music: A Reader, ed. and intr. Christine Lucia (Newcastle: Cambridge Scholars, 2005), xxv.

35 See Dominic Pettman, Sonic Intimacy: Voices, Species, Technics (Or, How to Listen to the World) (Stanford, CA: Stanford University Press, 2017), 74.

${ }^{36}$ I use deconstruction in the sense proposed by Jacques Derrida throughout this paper. Although Derrida himself contends that it is impossible to strictly define what is meant by deconstruction (and to translate the term déconstruction accurately), deconstruction is a political mode of critique, acting as a critique of ideological and societal structures. Jacques Derrida, 'Letter to a Japanese Friend', trans. David Wood and Andrew Benjamin, in Derrida and Différance, ed. David Wood and Robert Bernasconi (Evanston, IL: Northwestern University Press, 1985), 3.

37 This is my own English translation from the original French. Ari Gauthier, Carnet secret de Lakshmi (Saint-Denis: Edilivre, 2015), 6.
} 
In the above example, the canine narrator points to the subversion of the nature/culture divide, at the same time as the association with dogs as lower caste, places the Dog as a subaltern, non-human entity in Pondicherry. In her chapter on 'Dogs as Dalits in Indian Literature', Wendy Doniger explains how in India ' $[\mathrm{t}]$ exts about the lower castes are sometimes masked by narratives about dogs, standing in for the people now generally called Dalits'. ${ }^{38}$ Doniger's observations are strongly reminiscent of J. M. Coetzee's description of David Lurie as a Harijan (a term Gandhi used to refer to Dalits). The reference to 'Tripod Dog' also seems to figure as a pastiche of the three-legged dog (driepoot) in J. M. Coetzee's farm novel. ${ }^{39}$ The name Tripod Dog Baba thus becomes a metaphor for linguistic entaglement, with Tripod Dog Baba not being a name the dog chose for himself. Rather, it was chosen for him in what can be called an interpellative act. As Butler argues in her Excitable Speech (1997), although not all name-calling is injurious, 'being called a name is one of the first forms of linguistic injury that one learns'. ${ }^{40}$ This hailing, however, also opens up the possibility of resistance: 'If to be addressed is to be interpellated', Butler argues, 'then the offensive call runs the risk of inaugurating a subject in speech who comes to use language to counter the offensive call. ${ }^{41}$ Notably, Tripod Dog Baba only has agency in figuring as a posthumanist entity. And it is only within this framework that acts of resistance can take place. These acts of resistance are only made up of him asking that he be called by his 'full name', rather than the variants of his name that have interpellated him. Tripod Dog Baba, in other words, has no agency outside the linguistic framework, the Symbolic, that interpellates him as a subject. The name he calls his own has been chosen for him and has implicated him in an anthropocentric-linguistic framework, where he is forced to listen to 'His Master's Voice'.

Finally, it is also important to highlight the pitfalls that come with such a 'new materialist' and post-humanist reading. ${ }^{42}$ Responding to the question of an audience member (on whether the new materialisms and object-oriented ontology obscure issues around race and decolonization) during a discussion between law professor Patricia Williams and himself, post-colonial scholar Paul Gilroy asks: 'Are the books of the new materialists, the new ontologists, all the rest of them, overflowing with attempts to get to grips with the history of race and colonialism in the world? Funnily enough, no, they

\footnotetext{
${ }^{38}$ Wendy Doniger, On Hinduism (New York: Oxford University Press, 2014), 488.

${ }^{39}$ Driepoot (three-legged) is also the Afrikaans word for 'tripod'.

${ }^{40}$ Judith Butler, Excitable Speech: A Politics of the Performative (New York: Routledge, 1997), 2.

${ }^{41}$ Butler, 2.

${ }^{42}$ In recent years a form of philosophical inquiry termed new materialism (or neomaterialism) and objectoriented ontology has flourished in literary and cultural criticism. In her landmark Vibrant Matter (2010), Jane Bennett, for example, introduces the concept of 'vital materiality' as a means of cancelling out the modern enterprise of dichotomising the human and non-human, shifting the idea of attributing agency only to the human subject to all things: human and non-human alike. With this, laying out the basic tenants of what is termed the "material turn". Though I will, in this paper, often treat new materialism and object-oriented ontology synonymously, it has to be pointed out that, though they have many points of overlap, such as their quest for the Kantian Ding an sich, they are indeed two distinct streams. One of the main differences between object-oriented ontology and new materialism being new materialism's prioritisation of ethical and political ambitions. See Rick Dolphijn and Iris van der Tuin, 'Interview with Rosi Braidotti', in New Materialism: Interviews \& Cartographies, eds. Rick Dolphijn and Iris van der Tuin (Ann Harbor, MI: Open Humanities Press, 2012), pp. 19-37.
} 
aren't. And I suppose there are ways of reading that silence as a symptom. ${ }^{43}$ Arguably, years later, we are still confronted with this lack. And not just with this lack; we have to deal critically with the implications of agency in the non-human Other, which does not diminish the value of this Other, but recognizes its difference. Rather than equating and flattening the nature/culture divide, it is necessary to consider the different forms of agency that different species exhibit. Andreas Malm, in a polemical volume on the new materialisms, underscores this. Specifically in relation to the problematic use of 'agency' in these circles, he argues the following: 'Some animals [...] approximate certain features of language. But only humans routinely utilize complicated linguistic codes $[\ldots] .{ }^{44}$ And although, as cultural theorist Dominic Pettman correctly points out in his Sonic Intimacy: Voices, Species, Technics (2017), dogs too express themselves vocally and therefore express a certain type of acoustic agency, ${ }^{45}$ one has to be wary of endowing human 'sound' with those of the canine imaginary. This does not, however, mean that cross-species communication and agency cannot take place. It does, however, mean that these agencies are distinct from one another.

The examples in this article have, then, tentatively shown that sound can lend agency to animal subjectivity; not all forms of agency, should, however, be equated with the same agency attributed to human subjectivity. On the one hand, agency is granted through anthropomorphized figurations in plays such as Antigone (Not Quite/Quiet) and Craig Higginson's Dream of the Dog, where agency appears in the form of the non-linguistic that eludes the readable Symbolic. In the Gautier text, on the other hand, agency arises from the anthropomorphic act of speaking, where naming situates the dog in a linguistic framework, through which injurious speech can partly be countered. The dog in Secret carnet de Lakshmi has, then, been interpellated as the nonanimal author through linguistic means. It would therefore seem that both in multisensory media such as drama and one-dimensional media such as the novel, meaning is osmosed through sound to the visual world, opening up opportunities for resistance and worlding. ${ }^{46}$ Or, to conjure Jeremy Bentham again, 'resistance as sonic externalization rather than visual internalization'. ${ }^{47}$ In Global South contexts, such as India and South Africa, the idea of sound and animality thus become malleable concepts no longer solely fettered to an alphabetical and ideogrammatic monopoly. The literary figurations considered in this paper were treated as an archetype of the latter; representing forms that, by moving away from text, sought to counter its hegemony. Thus, showing us what may happen if text is re-staged in ways that move beyond the written word. 'Sound and South' and 'Non-human' are thus no longer simply posited as Other, but exist as forms embedded in a complex dialectic. And it is here - at the nexus of sound and animality - that the Other gains its strength. Notwithstanding this, it is arguable that agential difference has to be upheld to a certain extent, even if this runs the risks of reinscribing essentialist views. Derrida's well-known argument that ' $[\mathrm{t}] \mathrm{here}$ is no Animal in the general singular, separated from man by a single, indivisible

\footnotetext{
43 CRASSH, 'CRASSH Impact: In Conversation - Patricia Williams and Paul Gilroy'; available at http://www.crassh.cam.ac.uk/gallery/video/crassh-impact-paul-gilroy-and-patricia-williams-inconversation [accessed 8 September 2021], 1:22:50-1:33:29.

${ }_{44}$ Andreas Malm, The Progress of this Storm: Nature and Society in a Warming World (London: Verso, 2017), 167.

45 Pettman, 75; 96.

${ }^{46}$ Lynne Kendrick, Theatre Aurality (London: Palgrave Macmillan, 2017), xvii.

${ }^{47}$ Steintrager and Chow, 6.
} 
limit', ${ }^{48}$ therefore only holds insofar as there is difference within animal and sonic agency.

\section{Bibliography}

1. Anhalt, Emily Katz. Embattled: How Ancient Myths Empower Us to Resist Tyranny. Stanford, CA: Redwood Press, 2021.

2. Baderoon, Gabeba. 'Animal Likenesses: Dogs and the Boundary of the Human in South Africa'. Journal of African Cultural Studies 29.3 (2017): 345-61.

3. Barad, Karen. 'Posthumanist Performativity: Toward an Understanding of How Matter Comes to Matter'. Signs Journal of Women in Culture and Society 28.3 (2003): 801-31.

4. Baskaran, S. Theodore. The Book of Indian Dogs. New Delhi: Aleph, 2017.

5. Brooks, Daphne A. Linear Notes for the Revolution: The Intellectual Life of Black Feminist Sound. Cambridge, MA: Harvard University Press, 2021.

6. Butler, Judith. Excitable Speech: A Politics of the Performative. New York: Routledge, 1997.

7. Coetzee, J. M. Disgrace. New York: Viking Adult, 1999.

8. CRASSH. 'CRASSH Impact: In Conversation - Patricia Williams and Paul Gilroy'. Available at http://www.crassh.cam.ac.uk/gallery/video/crassh-impact-paul-gilroy-andpatricia-williams-in-conversation. Accessed 8 September 2021.

9. Derrida, Jacques. The Animal That Therefore I Am. Edited by Marie-Louise Mallet. Translated by David Wills. New York: Fordham University Press, 2008.

10.Derrida, Jacques. 'Letter to a Japanese Friend'. Translated by David Wood and Andrew Benjamin. In Derrida and Différance. Edited by David Wood and Robert Bernasconi. Evanston, IL: Northwestern University Press, 1985. 1-5.

11.Dolphijn Rick and Iris van der Tuin (Editors). New Materialism: Interviews \& Cartographies. Ann Harbor, MI: Open Humanities Press, 2012.

12.Doniger, Wendy. On Hinduism. New York: Oxford University Press, 2014. 488-500.

13.Fleishman, Mark et al. Antigone (Not Quite/Quiet). Filmed by Dex Goodman in 2019 at the Golden Arrow Studio, Baxter Theatre Centre. Cape Town, 2019.

14.Fleishman, Mark. 'Workshop Theatre in South Africa in the 1980s: A Critical Examination with Specific Reference to Power, Orality and the Carnivalesque'. MA Thesis University of Cape Town, 1991.

15.Gauthier, Ari. Carnet secret de Lakshmi. Saint-Denis: Edilivre, 2015.

16. Haraway, Donna. When Species Meet. Minneapolis: University of Minnesota Press, 2008.

17.Heidegger, Martin. Sein und Zeit. Eleventh Edition. Tübingen: Max Niemeyer, 1967.

18.Higginson, Craig. Three Plays: Dream of the Dog, The Girl in the Yellow Dress, The Imagined Land. London: Oberon Books, 2016.

19.Jameson, Fredric. The Ancients and the Postmoderns: On the Historicity of Forms. London: Verso, 2015.

20.Kay, Sarah. 'The Soundscape of Troubadour Poetry, or, How Human is Song'. Speculum 91.4 (2016): 1002-15.

21.Kay, Sarah, and Nicolette Zeeman. 'Versions of the Natural'. Journal of Medieval and Early Modern Studies 49.3 (2019): 445-56.

22.Kendrick, Lynne. Theatre Aurality. London: Palgrave Macmillan, 2017.

23. Kittler, Friedrich. Gramophone, Film, Typewriter. Stanford, CA: Stanford University Press, 1999.

24.LaBelle, Brandon. Sonic Agency: Sound and Emergent Forms of Resistance. London: Goldsmiths Press, 2018.

\footnotetext{
48 Jacques Derrida, The Animal That Therefore I Am, ed. Marie-Louise Mallet, trans. David Wills (New York: Fordham University Press, 2008), 47.
} 
25.Lacan, Jacques. Écrits. A Selection. Translated by Alan Sheridan. London: Routledge, 2001.

26.Lucia, Christine (Editor). The World of South African Music: A Reader. Introduced by Christine Lucia. Newcastle: Cambridge Scholars, 2005.

27.Malm, Andreas. The Progress of this Storm: Nature and Society in a Warming World. London: Verso, 2017.

28. Murphy, Emilie. 'The Racialisation of Sound and Listening in Anglophone Travel Narratives, c. 1550-1650'. In Travel, Transculturality, and Identity in England, c. 15501700. Available at http://www.tideproject.uk/wp-content/uploads/2021/07/TIDE_OnBelonging-2_Conference-Pack.pdf. Accessed 6 September 2021.

29.Nietzsche, Friedrich. Die Geburt der Tragödie: oder Griechentum und Pessimismus. Berlin: Hofenberg, 2016.

30.O'Callaghan, Casey. Sounds: A Philosophical Theory. Oxford: Oxford University Press, 2007.

31.Pettman, Dominic. Sonic Intimacy: Voices, Species, Technics (Or, How to Listen to the World). Stanford, CA: Stanford University Press, 2017.

32.Plato. Plato in Twelve Volumes. Volume 9. Translated by Harold N. Fowler. Cambridge, MA: Harvard University Press, 1925.

33. Steingo, Gavin, and Jim Sykes (Editors). Remapping Sound Studies. Introduced by Gavin Stenigo and Jim Sykes. Durham, NC: Duke University Press, 2019.

34. Steintrager, James A., and Rey Chow (Editors). Sound Objects. Introduced by James A. Steintrager and Rey Chow. Durham, NC: Duke University Press, 2019.

35.Sterne, Jonathan (Editor). The Sound Studies Reader. Abingdon: Routledge, 2012.

36.Vundla, Mandisa. 'Texts: Antigone Responses'. Available at https://retags100.wixsite.com/retagsproductions/antigone-not-quite-quiet-1. Accessed 26 February 2021.

37. West-Pavlov, Russell (Editor). The Global South and Literature. Introduced by Russel WestPavlov. Cambridge: Cambridge University Press, 2018.

\section{Un contra-text animal? Sunetul canin în Sudul Global}

\section{Rezumat}

Prejudecata vizuală a Vestului a modelat în mod decisiv critica literară și culturală din ultimele decenii. Perpetuată prin cotitura lingvistică, această prejudecată a plasat cuvântul scris în inima criticii (post)umaniste. Studiind tendințele actuale din teoria contemporană, devine evident că, odată cu declinul cotiturii lingvistice, studiile despre animale și despre sunete sunt în continuă creștere. Modelându-se tot mai mult după imaginația literară globală, poeticile canine, în mod particular, sunt prinse într-o complexă țesătură ideologică. Bazându-mi investigația pe o serie de opere literare și dramatice din Sudul Global, ca de exemplu piesa lui Mark Fleishman et al. Antigone (Not Quite/Quiet) (2019), piesa lui Craig Higginson Dream of the Dog (2007) şi romanul lui Ari Gauthier Carnet secret de Lakshmi (2015), argumentez că, în mod analog modului în care sunetul a câştigat putere crescută de actant în Sudul Global, tot astfel figuraţiile canine punctează modul în care simbolurile acustice pot fi rearticulate. 